\title{
Effects of Edible Micronized Chitosan Coating on Quality and Shelf Life of Sliced Papaya
}

\author{
Po-Jung Chien ${ }^{1 *}$, Hung-Ren Lin $^{2}$, Min-Sheng $\mathrm{Su}^{3}$ \\ ${ }^{1}$ Department of Horticulture and Biotechnology, Chinese Culture University, Taipei, Taiwan; ${ }^{2}$ Department of Horticulture, College \\ of Agriculture and Bioresources, National Taiwan University, Taipei, Taiwan; ${ }^{3}$ Department of Food Science, Yuanpei University, \\ Hsinchu City, Taiwan. \\ Email: "pojungchien@gmail.com
}

Received May $30^{\text {th }}, 2013$; revised June $30^{\text {th }}, 2013$; accepted July $7^{\text {th }}, 2013$

Copyright (C) 2013 Po-Jung Chien et al. This is an open access article distributed under the Creative Commons Attribution License, which permits unrestricted use, distribution, and reproduction in any medium, provided the original work is properly cited.

\begin{abstract}
Papaya pulp is very perishable and has a short shelf life. Manually sliced papayas were treated with $0 \%, 0.25 \%, 0.5 \%$, and $1 \%$ chitosan (non-micronized and micronized) aqueous solutions; placed into plastic trays, and over-wrapped with PVDC film and then stored at $4^{\circ} \mathrm{C}$. Color, soluble solid content, water loss, and total plate count of samples were evaluated. Chitosan coating had the ability to maintain the lightness of the sliced papayas. The a values of the micronized chitosan-coated sliced papayas were significantly lower than those of the-coated. The sliced papayas that had been treated with $1 \% \mathrm{MC}$ had a higher total soluble solid content and lower $\mathrm{b}^{*}$ value after four days of storage. Also, the chitosan coating on the sliced papaya effectively retarded water loss and inhibited the growth of microorganisms. The results reveal that applying a chitosan coating effectively maintained the quality attributes and prolonged the shelf life of the sliced papayas.
\end{abstract}

Keywords: Micronized Chitosan; Papaya; Minimal Processed Fruit; Quality; Shelf Life

\section{Introduction}

Papaya is a climacteric fruit. The climacteric respiration peak is observed at the 6 th day after harvest when papaya is harvested at the color break stage [1]. Normally, papaya fruit with at least 3\% skin yellowing has $11.5 \%$ total soluble solids [2] and the pulp firmness starts decreasing from approximately 240 to $50 \mathrm{~N}$ [3]. For convenience of serving and consumption, restaurants and consumers prefer to consume sliced papayas. Slicing and deseeding led to an increase in respiration, ethylene production, and flesh softening [4]. Minimal processed papaya is very perishable and has a short shelf life due to the increased tissue disruption, ethylene production, respiration, and transpiration [5-7]. Typically, minimally processed foods are stored between $4^{\circ} \mathrm{C}$ and $8^{\circ} \mathrm{C}$. However, shelf life of sliced papaya is about 2 days due to the flesh softening and off-odor [8]. Water loss is one of the major problems of sliced papaya. Sliced fruits are very perishable because they lack protective pericarp [9]. Additionally, the pulp is very vulnerable to dehydration, discoloration, and spoilage bacteria [10].

${ }^{*}$ Corresponding author.
Chitosan is a cationic polysaccharide with a high molecular weight and a linear polymer which is composed of $\beta$-1, 4-linked glucosamine ( $\mathrm{GlcN})$ with various quantities of N-acetylated GlcN residues. It is obtained by the alkaline deacetylation of chitin extracted from an abundant source of shellfish exoskeletons or the cell walls of some microorganisms and fungi [11]. Chitosan is soluble in dilute organic acids, and could theoretically be used as a preservative for coating fruit. The coating is non-toxic and safe [12], and exhibits antifungal activity against several fungi [13]. A chitosan coating is known to have the potential to prolong the storage life and control the decay of sliced mango, sliced red pitayas, strawberries, peaches, and longan fruits [14-17]. Coating fruit and vegetables with chitosan help the long-term storage of food [13] because a chitosan film could act as a type of active package. The preservatives are released from the film deposited on the surface of the food and these could inhibit spoilage bacteria.

The effect of molecular weight on the physical properties of chitosan membranes has been reported. Low molecular weight chitosans (LMWC) have permeability higher than that of high molecular weight chitosans 
(HMWC) [18]. LMWC with an average molecular weight in the range 5000 - 20,000 Da were shown to exhibit superior biological activities than chitosan [19]. Jeon, Park, and Kim [20] reported that LMWC had the highest bactericidal activity towards pathogenic bacteria. However, it seems that there is no information on the maintenance of quality of the sliced papayas using micronized chitosan (MC) coating. The aim of this research was to evaluate the potential use of a MC coating in controlling the decay, extending the postharvest life, and maintaining the quality of the sliced papayas during storage.

\section{Materials and Methods}

\subsection{Chitosan Coating Solution}

Chitosan $(\mathrm{Mw}=357 \pm 39 \mathrm{kDa})$ with $96.2 \%$ N-deacetylation were obtained from VA \& G Bioscience Inc. (Taoyuan, Taiwan). The non-micronized chitosan (NMC) was in powder form and prepared from crab shells. Before and after the micronization, the particle sizes of the micronization chitosan (MC) samples were estimated by the laser particle size analyzer (Analysette 22-Economy, Fritsch, Germany). To prepare one liter of $0.25 \%, 0.5 \%$ or $1 \%$ chitosan solutions, 2.5, 5.0 and $10.0 \mathrm{~g}$ of chitosan were dispersed in $900 \mathrm{ml}$ of distilled water to which $50 \mathrm{ml}$ of glacial acetic acid was added to dissolve the chitosan. The $\mathrm{pH}$ of the solution was adjusted to $\mathrm{pH} 5.0$ with 0.1 $\mathrm{M} \mathrm{NaOH}$ and the solution was made up to one liter. Acid solution without chitosan ( $\mathrm{pH}$ 5.0) was used as control.

\subsection{Plant Materials}

The papaya (Carica papara L., Tainung No. 2) used in the experiment was grown in Pingtung, Taiwan, and brought to the laboratory immediately after it was harvested. The fruit were selected for their uniformity, size, color, shape, and absence of damage and fungal infection. The 60 fruits were separated into groups of three, for treatment in triplicate. After washing, the fruit were peeled and sliced manually. The sliced papayas were then dipped into a chitosan coating solution for $1 \mathrm{~min}$. After they had been air-dried for $30 \mathrm{~min}$ at $25^{\circ} \mathrm{C}$, the sliced fruit were placed into plastic trays, and over-wrapped with $30 \times 20$ $\mathrm{cm}$ PVDC film (Wu-Yu Chemistry Co., Japan). They were then stored at $4^{\circ} \mathrm{C}$ to be later assessed.

\subsection{Color Analysis}

A CIELAB colorimetry system was used to determine the color. Coloration was determined using a ColorPen $^{\mathrm{TM}}$ handy color difference photometer (Dr. Bruno Lange $\mathrm{GmbH}$, Berlin, Germany), which recorded the spectrum of reflected light and converted it into a set of color coordinates ( $\mathrm{L}, \mathrm{a}^{*}$, and $\mathrm{b}^{*}$ values). Color coordinates range from $\mathrm{L}=0$ (black) to $\mathrm{L}=100$ (white), $-\mathrm{a}^{*}$ (greenness) to $+\mathrm{a}^{*}$ (redness), and $-\mathrm{b}^{*}$ (blueness) to $+\mathrm{b}^{*}$ (yellowness). A Minolta standard white plate $(\mathrm{X}=83.6$, $\mathrm{Y}=81.2, \mathrm{Z}=93.8)$ and a black plate were used to standardize the instruments.

\subsection{Total Soluble Solids Determination}

Pulp (100 g) from 10 fruits was homogenized in a grinder and then centrifuged at $3500 \mathrm{rpm}$ (Du-Pont, model Sorvall RC-5C) for $20 \mathrm{~min}$ to remove the pomace. The supernatant phase was collected to be analyzed for the amount of soluble solids (using a hand refractometer; ATAGO, model N1).

\subsection{Weight Loss Determination}

Three batches of 100 slices underwent each treatment. Ten slices were removed from each treatment daily. The slices were weighed regularly to determine weight loss, which was calculated cumulatively by comparing the weights of fruit immediately after slicing and treatment with chitosan after various storage times. The results were expressed as percentages.

\subsection{Microbiological Analysis}

A $10 \mathrm{~g}$ sample was obtained following homogenization in $90 \mathrm{ml} 0.1 \%$ peptone water (Difico, 0118-17-0). Other decimal dilutions were prepared from a $10^{-1}$ dilution. The total plate count was determined via the pour plate method, with Plate Count Agar (Difco, 0479-17) as the medium. The plates were incubated at $35^{\circ} \mathrm{C}$ for $48 \mathrm{~h}$. Three samples in each group were analyzed. All counts were presented as average values over three samples.

\subsection{Statistical Analysis}

Three analyses of each sample were performed and each experiment was performed in triplicate $(n=3)$. The mean values and the standard deviation were calculated based on the data obtained. These data were then compared using the Duncan's-multiple range method.

\section{Results and Discussion}

\subsection{Color}

The L value of the sliced papayas decreased with storage time (Table 1). After four days of storage, the $\mathrm{L}$ values of the fruit treated with chitosan coating solution did not vary significantly. However, the chitosan-coated sliced papayas and uncoated sliced papayas were significantly different $(\mathrm{p} \leq 0.05)$. The results indicate that chitosan coating had the ability to maintain the lightness of the sliced papayas. Surface color measurements showed that the $a^{*}$ value of the sliced papayas increased with storage time (Table 1). The $\mathrm{a}^{*}$ value of uncoated sliced papayas 
Table 1. Effect of non-micronized and micronized chitosan-coating on color and total soluble solids of sliced papaya during storage at $4^{\circ} \mathrm{C}$.

\begin{tabular}{|c|c|c|c|c|c|c|c|c|c|c|c|c|c|c|c|c|}
\hline Treatment & \multicolumn{4}{|c|}{$\mathrm{L}$} & \multicolumn{4}{|c|}{$a^{*}$} & \multicolumn{4}{|c|}{$\mathrm{b}^{*}$} & \multicolumn{4}{|c|}{ Total soluble solid (Brix) } \\
\hline \multicolumn{17}{|l|}{0 day } \\
\hline Control & 34.82 & \pm & 0.66 & $a b$ & 50.66 & \pm & 1.34 & $\mathrm{i}$ & 20.22 & \pm & 0.37 & $\mathrm{~b}$ & 11.30 & \pm & 0.53 & ba \\
\hline $0.25 \% \mathrm{NMC}$ & 35.14 & \pm & 0.58 & $\mathrm{ab}$ & 51.35 & \pm & 0.70 & $\mathrm{i}$ & 20.35 & \pm & 0.51 & $\mathrm{~b}$ & 11.17 & \pm & 0.47 & $\mathrm{ba}$ \\
\hline $0.5 \% \mathrm{NMC}$ & 35.53 & \pm & 0.45 & $\mathrm{ab}$ & 51.08 & \pm & 0.41 & $\mathrm{i}$ & 20.67 & \pm & 0.52 & $\mathrm{~b}$ & 10.70 & \pm & 0.96 & ba \\
\hline $1.0 \% \mathrm{NMC}$ & 35.35 & \pm & 0.61 & $\mathrm{ab}$ & 51.50 & \pm & 0.84 & $\mathrm{i}$ & 20.43 & \pm & 0.68 & $\mathrm{~b}$ & 10.87 & \pm & 0.71 & ba \\
\hline $0.25 \% \mathrm{MC}$ & 35.82 & \pm & 0.48 & a & 51.67 & \pm & 0.60 & $\mathrm{i}$ & 20.23 & \pm & 0.53 & $\mathrm{~b}$ & 10.73 & \pm & 0.55 & ba \\
\hline $0.5 \% \mathrm{MC}$ & 35.16 & \pm & 0.54 & $\mathrm{ab}$ & 51.40 & \pm & 0.48 & $\mathrm{i}$ & 20.35 & \pm & 0.53 & $\mathrm{~b}$ & 10.60 & \pm & 0.95 & $\mathrm{ba}$ \\
\hline $1.0 \% \mathrm{MC}$ & 34.71 & \pm & 0.42 & $\mathrm{~b}$ & 51.06 & \pm & 0.55 & $\mathrm{i}$ & 20.33 & \pm & 0.45 & $\mathrm{~b}$ & 11.27 & \pm & 0.55 & ba \\
\hline \multicolumn{17}{|l|}{2 day } \\
\hline Control & 30.37 & \pm & 0.64 & $\mathrm{e}$ & 68.72 & \pm & 0.91 & $\mathrm{c}$ & 20.58 & \pm & 0.55 & $\mathrm{~b}$ & 11.20 & \pm & 1.04 & ba \\
\hline $0.25 \% \mathrm{NMC}$ & 31.91 & \pm & 0.58 & $\mathrm{~d}$ & 66.46 & \pm & 0.55 & $\mathrm{~d}$ & 20.55 & \pm & 0.33 & $\mathrm{~b}$ & 11.20 & \pm & 0.36 & ba \\
\hline $0.5 \% \mathrm{NMC}$ & 32.47 & \pm & 0.53 & $\mathrm{~cd}$ & 64.53 & \pm & 0.95 & $\mathrm{e}$ & 20.74 & \pm & 0.44 & $\mathrm{~b}$ & 11.03 & \pm & 0.57 & ba \\
\hline $1.0 \% \mathrm{NMC}$ & 31.99 & \pm & 0.49 & $\mathrm{~d}$ & 60.20 & \pm & 1.28 & $\mathrm{f}$ & 20.81 & \pm & 0.40 & $\mathrm{~b}$ & 10.87 & \pm & 0.81 & ba \\
\hline $0.25 \% \mathrm{MC}$ & 32.33 & \pm & 0.65 & $\mathrm{~cd}$ & 61.56 & \pm & 0.90 & $\mathrm{f}$ & 20.53 & \pm & 0.40 & $\mathrm{~b}$ & 10.57 & \pm & 0.45 & ba \\
\hline $0.5 \% \mathrm{MC}$ & 31.95 & \pm & 0.39 & $\mathrm{~d}$ & 58.27 & \pm & 0.68 & $\mathrm{~g}$ & 20.47 & \pm & 0.53 & $\mathrm{~b}$ & 10.70 & \pm & 0.61 & ba \\
\hline $1.0 \% \mathrm{MC}$ & 33.16 & \pm & 0.57 & $\mathrm{c}$ & 55.22 & \pm & 0.63 & $\mathrm{~h}$ & 20.51 & \pm & 0.64 & $\mathrm{~b}$ & 11.27 & \pm & 0.57 & ba \\
\hline \multicolumn{17}{|l|}{4 day } \\
\hline Control & 27.97 & \pm & 0.58 & $\mathrm{f}$ & 75.91 & \pm & 0.67 & $\mathrm{a}$ & 21.89 & \pm & 0.67 & $\mathrm{a}$ & 11.80 & \pm & 0.50 & $\mathrm{a}$ \\
\hline $0.25 \% \mathrm{NMC}$ & 29.38 & \pm & 0.55 & $\mathrm{e}$ & 70.75 & \pm & 0.62 & $\mathrm{~b}$ & 21.08 & \pm & 0.47 & $\mathrm{ba}$ & 11.50 & \pm & 0.20 & ba \\
\hline $0.5 \% \mathrm{NMC}$ & 29.49 & \pm & 0.66 & $\mathrm{e}$ & 68.63 & \pm & 0.52 & $\mathrm{c}$ & 21.33 & \pm & 0.65 & ba & 11.43 & \pm & 0.60 & ba \\
\hline $1.0 \% \mathrm{NMC}$ & 29.49 & \pm & 0.43 & $\mathrm{e}$ & 66.73 & \pm & 1.05 & $\mathrm{~d}$ & 21.25 & \pm & 0.69 & ba & 11.57 & \pm & 0.29 & ba \\
\hline $0.25 \% \mathrm{MC}$ & 29.73 & \pm & 0.50 & $\mathrm{e}$ & 67.44 & \pm & 0.78 & $\mathrm{dc}$ & 21.09 & \pm & 0.30 & ba & 11.17 & \pm & 0.60 & ba \\
\hline $0.5 \% \mathrm{MC}$ & 29.53 & \pm & 0.57 & $\mathrm{e}$ & 63.33 & \pm & 1.10 & $\mathrm{e}$ & 21.04 & \pm & 0.52 & ba & 10.80 & \pm & 0.46 & ba \\
\hline $1.0 \% \mathrm{MC}$ & 30.32 & \pm & 0.54 & $\mathrm{e}$ & 60.24 & \pm & 0.67 & $\mathrm{f}$ & 20.71 & \pm & 0.57 & $\mathrm{~b}$ & 10.53 & \pm & 0.55 & $\mathrm{~b}$ \\
\hline
\end{tabular}

Within the same column, means followed by different letters are significantly different at $\mathrm{p}<0.05$.

increased significantly from $50.66 \pm 1.34$ to $75.91 \pm 0.67$ during four days of storage. The increase in the redness was probably caused by an increase in the respiration rate and the promotion of enzymatic processes that were responsible for a drop in quality of the fruit, which involved browning and other reactions. The $\mathrm{a}^{*}$ value associated with the chitosan treatment was lower than that of the control. Also, the $\mathrm{a}^{*}$ values of the MC-coated sliced papayas were significantly lower than those of the NMCcoated. After four days of storage, the $b^{*}$ value associated with the MC treatment $(1 \%)$ was significantly lower than that of the control. The yellowness of the 1\% MC-coated sliced papayas was not significantly changed after stor- age.

\subsection{Total Soluble Solids}

The total soluble solid contents did not vary significantly among the sliced papayas treated with $0.25 \%, 0.5 \%$ chitosan (non-micronized and micronized) and uncoated. The total soluble solid contents of all samples (coated and uncoated) were not significantly changed after two days of storage. However, the sliced papayas that had been treated with $1 \% \mathrm{MC}$ had a lower total soluble solid content after four days of storage (Table 1). Minimal processed papaya is very perishable and has a short shelf 
life due to the increased tissue disruption, respiration, and acceleration of fruit ripening (Rolle \& Chism, 1987; King \& Bolin, 1989; Watada \& Abe, 1990). The result indicates that the $1 \% \mathrm{MC}$ treatment had the ability to delay the ripening of the sliced papayas during storage, which could prolong their shelf life.

\subsection{Weight Loss}

Water loss or transpiration is another factor that affects the quality of fresh-cut papaya. A chitosan coating retarded the weight loss of the sliced papayas (Figure 1). Higher weight loss was observed in the control samples after two days of storage. After four days of storage, the weight losses of the control and 1\% MC-coated sliced papayas were $5.82 \%$ and $3.86 \%$, respectively. The weight loss was mainly due to transpiration and the leakage of juice from the pulp. Therefore, one of advantageous effect of chitosan coating on the loss of weight by papaya pulp was reducing transpiration and leakage of juice.

\subsection{Microbiological Analysis}

The total plate counts of uncoated, NMC-coated, and MC-coated sliced papayas were presented in Figure 2. The total plate counts of uncoated samples increased from 2.70 to $5.22 \log \mathrm{CFU} / \mathrm{g}$ at the end of the storage. After four days of storage, the total plate counts of the control and 1\% MC-coated sliced papayas were 5.22 and $3.45 \log \mathrm{CFU} / \mathrm{g}$, respectively. The chitosan coating on the sliced papaya effectively inhibited the growth of microorganisms.

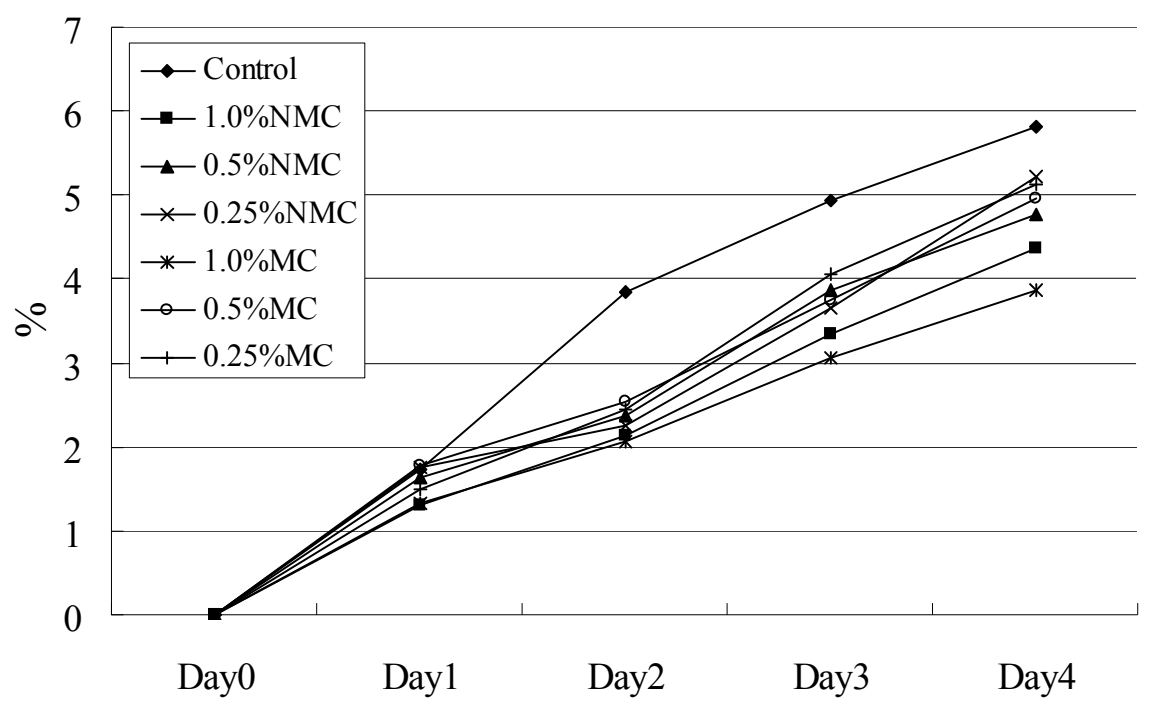

Figure 1. Effect of non-micronized and micronized chitosan-coating on weight loss of sliced papaya stored at $4^{\circ} \mathrm{C}$.

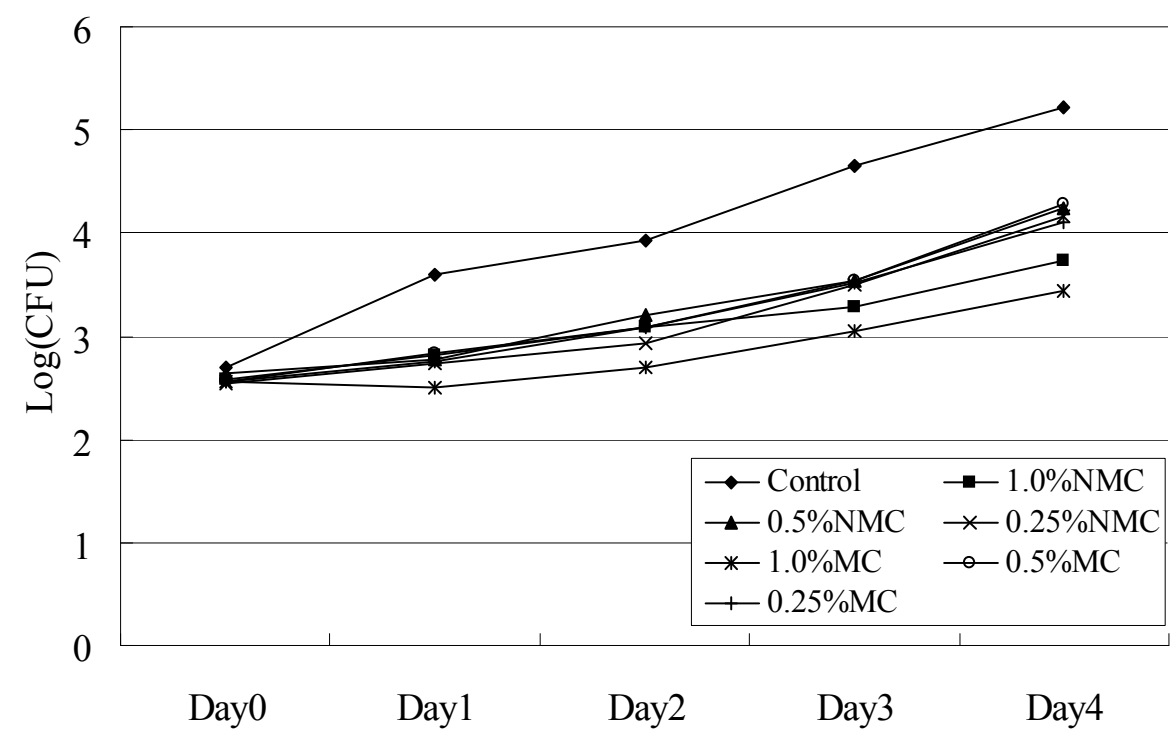

Figure 2. Effect of non-micronized and micronized chitosan-coating on total plate counts of sliced papaya stored at $4{ }^{\circ} \mathrm{C}$. 


\section{Conclusion}

After four days of storage, the $L$ values of the chitosancoated sliced papayas and uncoated sliced papayas were significantly different. The results indicate that chitosan coating had the ability to maintain the lightness of the sliced papayas. The $a^{*}$ values of the MC-coated sliced papayas were significantly lower than those of the NMCcoated. The sliced papayas that had been treated with $1 \%$ MC had a higher total soluble solid content and lower $\mathrm{b}^{*}$ value after four days of storage. Also, the chitosan coating on the sliced papaya effectively retarded water loss and inhibited the growth of microorganisms.

\section{REFERENCES}

[1] R. E. Paull and N. J. Chen, "Postharvest Variation in Cell Wall-Degrading Enzymes of Papaya (Carica papaya L.) during Fruit Ripening," Plant Physiology, Vol. 72, No. 2, 1983, pp. 382-385. doi: $10.1104 /$ pp.72.2.382

[2] E. K. Akamine and T. Goo, "Relationship between Surface Colour Development and Total Soluble Solids in Papaya," HortScience, Vol. 6, 1971, pp. 567-568.

[3] J. F. An and R. E. Paull, "Storage Temperature and Ethylene Influence on Ripening of Papaya Fruit," Journal of the American Society for Horticultural Science, Vol. 115, No. 6, 1990, pp. 949-953.

[4] R. E. Paull and W. Chen, "Minimal Processing of Papaya (Carica papaya L.) and the Physiology of Halved Fruit," Postharvest Biology and Technology, Vol. 12, No. 1, 1997, pp. 93-99. doi:10.1016/S0925-5214(97)00030-6

[5] R. S. Rolle and G. W. Chism, "Physiological Consequences of Minimally Processed Fruits and Vegetables," Journal of Food Quality, Vol. 10, No. 3, 1987, pp. 157177. doi:10.1111/j.1745-4557.1987.tb00856.x

[6] A. D. King and H. R. Bolin, "Physiological and Microbiological Storage Stability of Minimally Processed Fruits and Vegetables," Food Technology, Vol. 43, 1989, pp. 132-136.

[7] A. E. Watada, K. Abe and N. Yamuchi, "Physiological Activities of Partially Processed Fruits and Vegetables," Food Technology, Vol. 44, 1990, pp. 116-122.

[8] R. E. O'Connor-Shaw, R. Roberts, A. L. Ford and S. M. Nottingham, "Shelf Life of Minimally Processed Honeydew, Kiwifruit, Papaya, Pineapple and Cantaloupe," Journal of Food Science, Vol. 59, No. 6, 1994, pp. 1202-1206. doi:10.1111/j.1365-2621.1994.tb14676.x

[9] B. Tovar, H. S. Garcia and M. Mata, "Physiology of Pre-
Cut Mango. II. Evolution of Organic Acids," Food Research International, Vol. 34, No. 8, 2001, pp. 705-714. doi:10.1016/S0963-9969(01)00092-8

[10] E. A. Baldwin, M. O. Nisperos-Carried and R. A. Baker, "Use of Edible Coating for Lightly Processed Fruits and Vegetables," HortScience, Vol. 30, 1995, pp. 35-38.

[11] S. Hirano, Y. Ohe and H. One, "Selective N-Acetylation of Chitosan," Carbohydrate Research, Vol. 47, No. 2, 1976, pp. 315-320. doi:10.1016/S0008-6215(00)84198-1

[12] S. Hirano, C. Itakura, H. Seino, Y. Akiyama, I. Nonata and N. Kanbara , "Chitosan as an Ingredient for Domestic Animal Feeds," Journal of Agriculture and Food Chemistry, Vol. 38, 1990, pp. 1214-1217.

[13] A. El Ghaouth, J. Arul, J. Grenier and A. Asselin, "Antifungal Activity of Chitosan on Two Postharvest Pathogens of Strawberry Fruits," Phytopathology, Vol. 82, No. 4, 1992, pp. 398-402. doi:10.1094/Phyto-82-398

[14] P. J. Chien, F. Sheu and H. R. Lin , "Quality Assessment of Low Molecular Weight Chitosan Coating on Sliced Red Pitayas," Journal of Food Engineering, Vol. 79, No. 2, 2007, pp. 736-740. doi:10.1016/j.jfoodeng.2006.02.047

[15] P. J. Chien, F. Sheu and F. H. Yang, "Effects of Edible Chitosan Coating on Quality and Shelf Life of Sliced Mango Fruit," Journal of Food Engineering, Vol. 78, No. 1, 2007, pp. 225-229. doi:10.1016/j.jfoodeng.2005.09.022

[16] A. El Ghaouth, J. Arul, R. Ponnamapalam and M. Boulet, "Chitosan Coating Effect on Storability and Quality of Fresh Strawberries," Journal of Food Science, Vol. 56, No. 6, 1991, pp. 1618-1620. doi:10.1111/j.1365-2621.1991.tb08655.X

[17] Y. Jiang and Y. Li, "Effects of Chitosan Coating on Postharvest Life and Quality of Longan Fruit," Food Chemistry, Vol. 73, No. 2, 2001, pp. 143-159. doi:10.1016/S0308-8146(00)00246-6

[18] R. H. Chen and H. D. Hwa, "Effect of Molecular Weight of Chitosan with the Same Degree of Deacetylation on the Thermal, Mechanical, and Permeability Properties of the Prepared Membrane," Carbohydrate Polymers, Vol. 29, No. 4, 1996, pp. 353-358. doi:10.1016/S0144-8617(96)00007-0

[19] C. Muzzarelli and R. A. Muzzarelli, "Natural and Artificial Chitosan-Inorganic Composites," Journal of Inorganic Biochemistry, Vol. 92, No. 2, 2002, pp. 89-94. doi:10.1016/S0162-0134(02)00486-5

[20] Y. J. Jeon, P. J. Park and S. K. Kim, "Antimicrobial Effect of Chitooligosaccharides Produced by Bioreactor," Carbohydrate Polymers, Vol. 44, No. 1, 2001, pp. 71-76. doi:10.1016/S0144-8617(00)00200-9

\author{
Abbreviations \\ NMC: non-micronized chitosan \\ MC: micronized chitosan \\ PVDC: polyvinylidenechloride
}

